GLOBAL JOURNAL OF EDUCATIONAL RESEARCH VOL 9, NO. 1\&2 2010: 1-5

COPYRIGHT@ BACHUDO SCIENCE CO. LTD PRINTED IN NIGERIA. ISSN 1596-6224 www.globaljournalseries.com; Info@globaljournalseries.com

\title{
SOME AFFECTIVE CHARACTERISTICS AS CORRELATES OF SECONDARY SCHOOL STUDENTS PERFORMANCE IN MATHEMATICS IN CROSS RIVER STATE
}

P. U BASSEY, A. J. ISANGEDIGHI, O. MAUREEN OKON AND IDAKA E. IDAKA

(Received 4, May 2010; Revision Accepted 26, May 2010)

\begin{abstract}
The purpose of this study was to determine whether some affective characteristics could be used as correlates of secondary school students' performance in mathematics in Cross River State. A survey data from a sample of 500 students were used in the study. A total of three hypotheses were tested using the One-way Analysis of Variance (ANOVA) and the independent t-test statistics. The findings of the study showed a significant influence of achievement-motivation, attitude and gender on students' mathematics performance. This study results also showed that students' who manifested high, moderate and low achievement motivation differed significantly, while those with positive attitude perform better than their counterparts with negative attitude. In terms of gender, female students showed a positive attitude towards mathematics than male counterparts. Some recommendations were made for counseling implication.
\end{abstract}

\section{INTRODUCTION}

Science education is pivotal for national development, and it is the bedrock of any meaningful scientific and technological advancement of any society. Mathematics has come to regard as the language of science. Little wonder, the Federal Government of Nigeria via the National Policy on Education (2004) revised stipulates that, Mathematics must be taught as a compulsory subject to students at both the Basic Education level and Secondary school level. Mathematics is also a compulsory subject for those candidates who wish to pursue sciences and science related courses at the tertiary level.
Although, the importance of mathematics to the science student and any nation desirous of making fundamental breakthrough in science and technology is well documented in the literature, one still finds so much aversion for mathematics among students. This has manifested in students' poor performance in Mathematics and science subjects in public examination in Nigeria.

Statistics on Senior Secondary Certificate Examination (SSCE) result in Cross River State from 1999-2001 as analyzed by Bassey (2002), revealed a very poor performance by students in Mathematics. Table 1 is a summary of the results for the three years.

P. U Bassey, Department of Educational Foundation, Guidance and Counselling, University of Calabar, Nigeria

A. J. Isangedighi, Department of Educational Foundation, Guidance and Counselling, University of Calabar, Nigeria

O. Maureen Okon, Department of Educational Foundation, Guidance and Counselling, University of Calabar, Nigeria

I. E. Idaka, Cross River University of Technology, Calabar, Nigeria 
Table 1:

\begin{tabular}{llrrrr}
\hline Year & No of Students No of students No of & \multicolumn{2}{c}{$\begin{array}{l}\text { with credit pass } \\
\text { and above }\end{array}$} & failure Pass & failure \\
\hline 1999 & 76,966 & 31.080 & 45,822 & 40.88 & 59.54 \\
2000 & 75,481 & 20,142 & $55,28626.68$ & 73.25 \\
2001 & 73,321 & 20,021 & $53,25322.31$ & 72.63 \\
\hline
\end{tabular}

Source: $\quad$ WAEC, Yaba, Lagos (2001)

This unfortunate trend has its negative effect on students' ability to read sciences or sciencerelated courses at the tertiary levels. This scenario is unfortunate and unacceptable and accusing finger has been pointed at several directions; the Government, school system, teachers, students and even parents. However, Anagtogun (1986) attributed mass failure in Mathematics in particular and science in general to deficiency in the students' cognitive, affective and manipulative existing behaviour.

In this study, the researchers were basically interested in the affective characteristics of the students and how it influences their performance in Mathematics. Commenting on the influence of achievement motivation, Erekosina (1990) and Bassey (2002), agreed that there exist a significant relationship between achievement motivation and students academic performance.

Similarly, Ogban (1991) opined that achievement motivation correlated significantly with students' academic performance.

Commenting on the influence of attitude, Okpala (1996), Orute and Nwagu (1997) and Bassey (2002), all agreed that students' attitudes towards Mathematics will influence their performance in the students'

Government at various levels have invested so much in training and retraining of teachers, in the payment of science allowance and in the provision of textbooks, yet, there have not been any substantial improvement in Mathematics performance. Several other factors have also been investigated and appropriate recommendations implemented.

This present study therefore seeks to determine the role of the students' affective characteristics in their Mathematics performance. Specifically, the study is intended to determine;
1. The influence of achievement motivation on Mathematics performance.

2. The influence of attitude to students' Mathematics performance.

\section{Reseearch Hypothesis}

1. There is no significant influence of achievement motivation on students' mathematics performance.

2. There is no significant different among students' who showed positive and negative attitude with regards to their mathematics performance.

3. Gender has no significant influence on students' achievement motivation and attitude towards mathematics performance.

\section{Research Methodology}

The descriptive survey design was adopted for this study, and the population consisted of all secondary school students in the Southern Senatorial District of Cross River State, numbering about 14,277. The stratified and simple random sampling techniques were used to select the 500 respondents (246 males and 254 females) that constituted the sample. The research instruments were the Student Opinion Questionnaire (SOQ) and a Mathematics Achievement Test (MAT). The SOQ and MAT were developed by the researchers from literature experience. The SOQ had three sections; $A, B$, and $C$.

Section A: elicited information from the students on their demographic data as age, sex, class, school, occupation and educational qualification of parents.

Section B: the instrument was a 10-items, sixpoint Likert type self administered achievement motivation scale. Items in this scale was adapted 
from the Modified Achievement Questionnaire (MAQ) constructed by Craudal V.E. and Craudal V.J (1965) with a reliability of Croubach Alpha of 58. Some of the items included statements like "I am very happy until I set all questions corrects, "I desire nothing but the best in my academic"

Section C: was a 10 items, six point Likert- type scale designed to measure respondents attitude towards mathematics adapted from the attitude inventory Side (AIS: Coppersmith, 1967). Some of the statements included "I dislike mathematics", "I hate mathematics as a school subject".

\section{ANALYSIS OF DATA AND RESULT}

Hypothesis - by - hypothesis analysis and presentation is presented here.

\section{Hypothesis One:}

There is no significant difference among students who manifests high, moderate and low achievement motivation with regards to their mathematics performance. A one-way analysis of variables statistical techniques was adopted in testing this hypothesis. The results of the analysis are as shown in Table 1

Mean standard deviation and One-way analysis of the influence of achievement motivation on students' mathematics performance.

\begin{tabular}{|c|c|c|c|c|c|}
\hline $\begin{array}{l}\text { Level of Achievement } \\
\text { Motivation (AM) }\end{array}$ & & $\mathbf{N}$ & $\overline{\mathbf{X}}$ & & SD \\
\hline High & & 62 & 55.95 & & 10.85 \\
\hline Moderate & & 244 & 49.77 & & 10.85 \\
\hline Low & & 194 & 47.16 & & 9.31 \\
\hline Total & & 500 & 49.53 & & 10.62 \\
\hline Source of variable & SS & df & MS & & F- \\
\hline \multicolumn{6}{|l|}{ ratio } \\
\hline Between group & & 366.16 & 2 & 1830.58 & $17.28^{*}$ \\
\hline Within group & & 52655.50 & 497 & 105.95 & \\
\hline Total & & 56316.66 & 499 & & \\
\hline
\end{tabular}

${ }^{*} P<.05, \mathrm{df}=2,477 ; \mathrm{f}=3.00$

The result of the analysis in Table 1 shows a significant f-ratio of 17.28 at .05 alpha levels and with 2 and 497 degrees of freedom, which is greater than the tabulated f-ratio of 3.00 . The null hypothesis is therefore rejected. In other words, there is a significant difference among students who manifest high, moderate and low achievement motivation with regards to their Mathematics performance.

A further analysis to determine the groups differences in their Mathematics performances, was done using Fisher's LSD multiple comparison test. The results of this analysis is as resented in Table 2

Table Two:

Results of Fisher's LSD on multiple comparison analysis of the influence of achievement motivation on students' Mathematics performance.

\begin{tabular}{llll}
\hline $\begin{array}{l}\text { Level of achievement } \\
\text { motivation }\end{array}$ & $\begin{array}{l}\text { Low } \\
(\mathbf{n = 1 9 4 )}\end{array}$ & $\begin{array}{l}\text { Moderate } \\
(\mathbf{n}=\mathbf{2 4 4})\end{array}$ & $\begin{array}{l}\text { High } \\
\mathbf{( n = 6 2 )}\end{array}$ \\
\hline Low & $43.20^{\mathrm{a}}$ & $-7.22^{\circ}$ & -19.30 \\
Moderate & $-9.14^{* \mathrm{c}}$ & 50.42 & -12.08 \\
High & -5.85 & -4.23 & 62.50 \\
& $\mathrm{MSW}$ & $=105.95$ & \\
\hline
\end{tabular}

${ }^{*} \mathrm{P}<.05$, critical $\mathrm{t}=1.96$

a. $\quad=\quad$ Group means placed diagonally

$\mathrm{b}=\quad$ Mean difference placed above the diagonal

c $\quad=\quad$ Fisher's LSD t-value placed below the diagonal 
The results of the post hoc indicate that students with high level of achievement motivation had a significantly high performance than those with moderate and low level of achievement motivation. Similarly, students with moderate level of achievement motivation had a significant, high mean performance than students with low level of achievement motivation.

\section{Hypothesis Two}

There is no significant difference among students who positive and negative attitude with regards to their Mathematics performance. To test this hypothesis, the independent t-test was used to compare students adjudged to have positive attitude with those who have negative attitude in respect of their mathematics performance. The result of data analysis is as presented in Table 3.

Table Three

\begin{tabular}{lllllll}
\hline Variables & Group N & X & & SD & df & t \\
\hline Attitude & positive 296 & 33.28 & & 7.12 & 498 & $3.22^{*}$ \\
& Negative & 204 & 31.09 & & 8.75 & \\
\hline
\end{tabular}

* $\quad \mathrm{P}<.05$, critical $\mathrm{t}=1.96$

The results in Table 3 indicates that a significant t-test of 3.22 which was greater than the critical tvale of 1.96. This implies that the attitude of students has a significant role in their Mathematics performance. In otherwords, students who displayed positive attitude $(x=$ 33.28) performed better than their counterparts with negative attitude $(x=31.09)$.

\section{Hypothesis Three}

Gender has no significant influence on students' achievement motivation and attitude with regards to their Mathematics performance. The independents t-test was used to compare male and female students. The result of data analysis is as presented in Table 4.

Table Four

An Independent t-test analysis of gender influence on students' achievement motivation and attitude

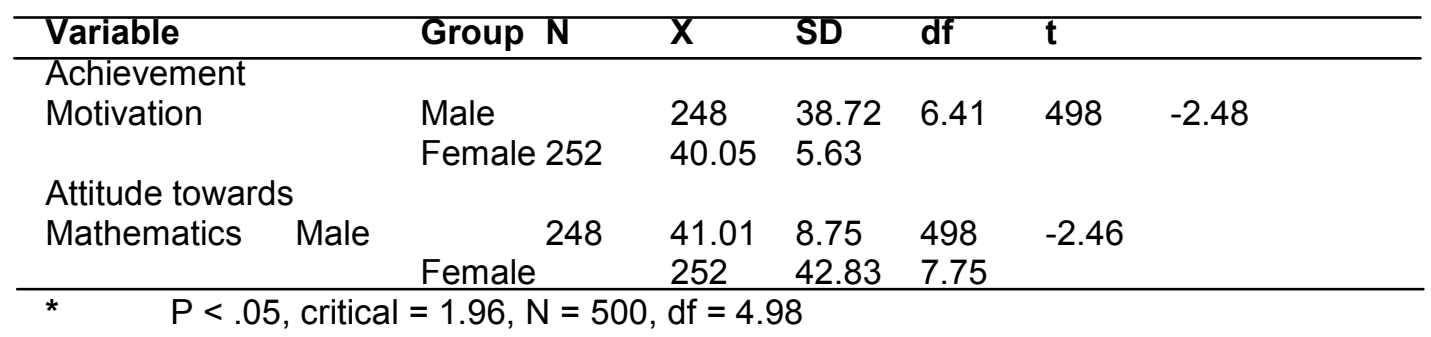

The results in Table 4 showed that when the influence of gender on students' achievement motivation was tested, a significant t-value of 2.45 at .05 and 4.98 degrees of freedom was obtained. The hypothesis for this case is thus rejected. This implies that, gender has a significant influence on their achievement motivation, in favour of the students' $(x=40.05)$.

With regards to gender on students' attitude towards Mathematics, a significant tvalue of -2.46 was also obtained which also resulted in the rejection of this point of the hypothesis. This also implies that, gender has a significant influence on their attitude towards Mathematics and also in favour of the female students' $(x=42.83)$. In otherwords, female students' have positive attitude towards Mathematics than their male counterparts.

\section{DISCUSSION}

The first and the major finding of this study is that secondary school students; sampled indicated that, achievement motivation 
significantly influence their performance in mathematics. This finding is consistent with the findings of Erekosima (1996), Bassey (2002) and Ogban (1991).

On the directionality of the influence on performance, the result indicated that the higher the achievement motivation, the better the performance. It therefore follows that, students with moderate achievement motivation performed better than their counterparts with low achievement motivation level.

The second finding of this study showed that, students' with positive attitude towards Mathematics performed better than their counterparts with negative attitude. This finding collaborate those of Okpala (1996), Ovute \& Nwagu (1997) and Bassey (2002). This findings is not surprising and attitude is a pre-disposition to behaviour and are positively related to each other. Ofcourse, students' with positive attitude would normally show a high level of interest in school subjects and such interest would enable them to excel in school (Bassey, 2002).

Finally, students' sampled for this study indicated that, gender is significantly related to their achievement motivation and attitude towards Mathematics. This findings also collaborates that of Bassey (2002). In that study Bassey (2002) opined that, the superiority of female have arouse as a result of the fact that under the test situation they (female) were more determined than their male counterparts to express positive attitude. Otherwise, attitude and even achievement motivation is purely a function of culture and sheer determination on the part of the student irrespective of gender.

It is therefore necessary that inherent negative behaviour and low-level achievement motivation should be replaced by a positive attitude and high-level achievement motivation; if improvement in Mathematics as a core suspect is to be achieved among our secondary school students'.

Students' should be helped through collaborative programmes between the school and the state government to the intent that the students develop in themselves a positive perception of themselves and discover their potential for excellence.

Also, that teachers of Mathematics should make the subject of mathematics very interesting and existing to students'.

Teachers should create more classroom interaction to stimulate increased attraction, connection effect and willingness on the part of the students to acquire knowledge.

\section{REFERENCES}

Anaghogun, M. A., 1986. Deficiency in Science entry Behaviour as a Cause of Mass Failure in Science. In Ayninde D.(Orf). Man Failure in Public Examination: Causes and Problems. Proceedings of the National Conference on Mass Failure in Public Examination.

Bassey, P. U., 2002. Affective Characteristics and Students' Performance in Mathematics in Southern Senatorial District of Cross River State. Unpublished M.Ed. Thesis: University of Calabar, Calabar.

Eriksosima, I.A., 1996. Personality Factor in Study Habit and Social Adjustment among Adolescent Learners in River State. Unpublished Ph.D. Thesis: University of Calabar, Calabar.

National Policy on Education., 2004. Federal Republic of Nigeria. Lagos: Nigeria.

Ogban, U.I., 1991. Motivation and Academic Achievement of JSS Students; of Cross River State. Unpublished M.Ed. Thesis: University of Calabar, Calabar.

Okpala, P. N., 1998 Attitude of Nigerian Secondary School Physics Teachers' Instructional Practices: In S.O. Ayodele (Ed). Education in the Service of Humility. Ibadan: U. I. Press 
APPENDIX I

SECTION B

\begin{tabular}{|l|l|l|l|l|l|l|l|}
\hline & Achievement motivation scale & VSA & SA & A & D & SD & VSD \\
\hline 1 & $\begin{array}{l}\text { I always ensure hat, my scores do not fall } \\
\text { below 60\% }\end{array}$ & & & & & & \\
\hline 2 & $\begin{array}{l}\text { I am never happy unless I come first in the } \\
\text { class }\end{array}$ & & & & & & \\
\hline 3 & $\begin{array}{l}\text { I hardly have enough time at home to study } \\
\text { as hard as I wish }\end{array}$ & & & & & & \\
\hline 4 & $\begin{array}{l}\text { I desire nothing but praises for academic } \\
\text { excellence in the school }\end{array}$ & & & & & & \\
\hline 5 & $\begin{array}{l}\text { I am never happy unless I get all questions } \\
\text { correct in examination }\end{array}$ & & & & & & \\
\hline 6 & $\begin{array}{l}\text { I desire nothing but the best in my school } \\
\text { work }\end{array}$ & & & & & & \\
\hline 7 & Subjects & & & & & & \\
\hline a. & Mathematics & & & & & & \\
\hline b. & English Language & & & & & & \\
\hline c. & Geography & & & & & & \\
\hline d. & Biology & & & & & & \\
\hline e. & Physics & & & & & & \\
\hline f. & Chemistry & & & & & & \\
\hline g. & Literature & & & & & & \\
\hline h. & Agric. Science & & & & & \\
\hline i. & Bible Knowledge & & & & & & \\
\hline j. & Government & & & & & & \\
\hline k. & Further Mathematics & & & & & \\
\hline 8 & $\begin{array}{l}\text { If you could go as far as you wanted } \\
\text { academically how far would you go? B.Sc. }\end{array}$ & & & & & & \\
\hline 9 & $\begin{array}{l}\text { I have the tendency to give up too quickly } \\
\text { when I run into difficulty }\end{array}$ & & & & & & \\
\hline 10 & I feel sad when I am absent from school & & & & & & \\
\hline
\end{tabular}

Listed above are some subjects offered at the Senior Secondary level. Look well and find the subjects you are offering for the (S.S.C.E) forthcoming final exam and tick [V] indicating the grades you are mostly like to make. 


\section{APPENDIX II}

\section{SECTION C}

\begin{tabular}{|c|c|c|c|c|c|c|c|}
\hline & Attitude scale & VSA & SA & A & $\mathrm{D}$ & SD & VSD \\
\hline 1 & I like Mathematics as a school subject & & & & & & \\
\hline 2 & $\begin{array}{l}\text { My Mathematics teacher takes time to } \\
\text { explain concepts and theorems etc }\end{array}$ & & & & & & \\
\hline 3 & $\begin{array}{l}\text { I enjoy discussing Mathematics problems } \\
\text { with my colleagues during Mathematics } \\
\text { class }\end{array}$ & & & & & & \\
\hline 4 & $\begin{array}{l}\text { There is no science equipment or manuals } \\
\text { in my school for effective learning of } \\
\text { Mathematics }\end{array}$ & & & & & & \\
\hline 5 & $\begin{array}{l}\text { I will like to be a Mathematician so that I can } \\
\text { contribute to my country's scientific } \\
\text { development }\end{array}$ & & & & & & \\
\hline 6 & $\begin{array}{l}\text { I find myself getting confused during school } \\
\text { subject }\end{array}$ & & & & & & \\
\hline 7 & $\begin{array}{l}\text { Mathematics should not be made a } \\
\text { compulsory schools subject }\end{array}$ & & & & & & \\
\hline 8 & $\begin{array}{l}\text { don't think I derive joy in passing } \\
\text { Mathematics exams }\end{array}$ & & & & & & \\
\hline 9 & $\begin{array}{l}\text { I don't like assignments because it does not } \\
\text { give me enough time to play around }\end{array}$ & & & & & & \\
\hline 10 & $\begin{array}{l}\text { I will like to be a member of Mathematics } \\
\text { club than a member of a music club }\end{array}$ & & & & & & \\
\hline
\end{tabular}

